\title{
Antiviral and Antioxidant Activities of Sulfated Galactomannans from Plants of Caatinga Biome
}

\author{
Márcia Maria Mendes Marques, ${ }^{1}$ Selene Maia de Morais, ${ }^{1,2}$ Ana Raquel Araújo da Silva, \\ Naiara Dutra Barroso, ${ }^{2}$ Tadeu Rocha Pontes Filho, ${ }^{1}$ \\ Fernanda Montenegro de Carvalho Araújo, ${ }^{3}$ Ícaro Gusmão Pinto Vieira, ${ }^{4}$ \\ Danielle Malta Lima, ${ }^{5}$ and Maria Izabel Florindo Guedes ${ }^{1}$ \\ ${ }^{1}$ Postgraduate Program of Biotechnology, Ceará State University, Avenue Dr. Silas Munguba 1700, Campus do Itaperi, \\ 60714-903 Fortaleza, CE, Brazil \\ ${ }^{2}$ Course of Chemistry, Ceará State University, Avenue Dr. Silas Munguba 1700, Campus do Itaperi, 60714-903 Fortaleza, CE, Brazil \\ ${ }^{3}$ Public Health Central Laboratory of Ceará, Avenue Barão de Sturdat 2405, 60120-002 Fortaleza, CE, Brazil \\ ${ }^{4}$ Technological Development Park (PADETEC), Federal University of Ceará, Campus do Pici, 60455-970 Fortaleza, CE, Brazil \\ ${ }^{5}$ Health Sciences Center, University of Fortaleza, Avenue Washington Soares 1321, 60811-905 Fortaleza, CE, Brazil
}

Correspondence should be addressed to Selene Maia de Morais; selenemaiademorais@gmail.com

Received 1 April 2015; Revised 11 June 2015; Accepted 16 June 2015

Academic Editor: Orazio Taglialatela-Scafati

Copyright (C) 2015 Márcia Maria Mendes Marques et al. This is an open access article distributed under the Creative Commons Attribution License, which permits unrestricted use, distribution, and reproduction in any medium, provided the original work is properly cited.

\begin{abstract}
Dengue represents a serious social and economic public health problem; then trying to contribute to improve its control, the objective of this research was to develop phytoterapics for dengue treatment using natural resources from Caatinga biome. Galactomannans isolated from Adenanthera pavonina L., Caesalpinia ferrea Mart., and Dimorphandra gardneriana Tull were chemically sulfated in order to evaluate the antioxidant, and antiviral activities and the role in the inhibition of virus DENV-2 in Vero cells. A positive correlation between the degree of sulfation, antioxidant and antiviral activities was observed. The sulfated galactomannans showed binding to the virus surface, indicating that they interact with DENV-2. The sulfated galactomannans from C. ferrea showed $96 \%$ inhibition of replication of DENV-2 followed by D. gardneriana (94\%) and A. pavonina $(77 \%)$ at $25 \mu \mathrm{g} / \mathrm{mL}$ and all sulfated galactomannans also showed antioxidant activity. This work is the first report of the antioxidant and antiviral effects of sulfated galactomannans against DENV-2. The results are very promising and suggest that these sulfated galactomannans from plants of Caatinga biome act in the early step of viral infection. Thus, sulfated galactomannans may act as an entry inhibitor of DENV-2.
\end{abstract}

\section{Introduction}

Dengue is considered the most important arthropod-borne viral disease in the world in terms of morbidity and mortality in humans. Dengue represents a serious social and economic public health problem in the 21st century [1]. An estimated 50 million dengue infections and approximately 20,000 deaths occur annually [2]. The infection is caused by the dengue virus (DENV), a member of the family Flaviviridae, genus Flavivirus and has four antigenically distinct serotypes, DENV-1, DENV-2, DENV-3, and DENV-4. DENV causes a spectrum of disease in humans, ranging from acute febrile dengue fever (DF) to severe forms [3]. There is still no effective treatment against the virus. Thus, extensive efforts have been made toward the development of vaccines and the discovery of potent therapeutic compounds against DENV. Research for dengue antiviral has focused on the different phases of the viral lifecycle (virus attachment, viral entry, trafficking, translation, or replication). Nevertheless, only few antiviral therapies have been tested and little is known about the effects and mechanisms of the antiviral agents [4].

Many studies have confirmed that the naturally sulfated polysaccharides such as polysaccharides from seaweed [5-8] 
and glycosaminoglycan [9] are potent inhibitors of dengue virus in vitro infection, apparently based on the structural similarities to heparan sulfate (HS), a putative receptor present in mammalian cells membranes. HS was reported as receptor molecule for DENV-2 in Vero cells [10]. The sulfated polysaccharides compete with HS for binding to the virus and thus inhibit the entrance of virus in the cell [11, 12].

The importance of free radical molecular species in the pathogenesis of various viral diseases has been increasingly recognized in recent years. Oxygen radicals such as superoxide $\left(\mathrm{O}_{2}^{-}\right)$and hydroxyl radical $(\mathrm{OH})$ have been implicated as possible pathogenic molecules in viral disease pathogenesis [13]. Chen et al. [14] observed that oxidative stress was detected in the Aedes aegypti mosquito infected cells. Despite this, the survival of mosquito cells benefits from the upregulation of genes related to antioxidant defence, such as glutathione $\mathrm{S}$ transferase (GST).

Viral Infection diseases constitute a major health problem throughout the world. Controlling these diseases is the subject of constant scientific efforts, due to the resistance to known antiviral agents. One very promising approach is the screening of antiviral products derived from natural sources, especially plants. Adenanthera pavonina L., Caesalpinia ferrea Mart., and Dimorphandra gardneriana Tull are native plants from Caatinga biome of Northeastern Brazil and have been used for the treatment of many diseases: A. pavonina has been reported to possess antibacterial $[15,16]$, antioxidant [17], anthelmintic [18], antihyperlipidemic [19], blood pressure lowering [20], and anti-inflammatory [21] effects. Pharmacological properties of $C$. ferrea include hypoglycemic $[22,23]$, antimicrobial [24], anticancer [25, 26], anti-inflammatory $[27,28]$, and analgesic [28].

There is a commercial interest in D. gardneriana whose fruits are used for rutin extraction, a flavonoid with several antioxidant [29], antiviral [30], antitumor [31], antiinflammatory [32], and leishmanicidal and anticholinesterase [33] properties. The seeds of this plant are also sources of galactomannans, storage polysaccharides of higher plants. Previous reports indicate the potential of sulfated galactomannans against dengue and yellow fever virus [34], herpes simplex virus [35-37], and poliovirus [37]. As a by-product of the rutin extraction from fruits, the seed galactomannans can be extracted and sulfated to produce sulfated galactomannans to be tested against dengue virus.

In the present study, galactomannans were extracted not only from the seeds of Dimorphandra gardneriana (Tul.) but from two other plants from Caatinga biome Adenanthera pavonina (L.) and Caesalpinia ferrea (Mart.) to establish a comparison between different galactomannans. These polysaccharides were sulfated with chlorosulfonic acid and then the sulfated galactomannans were evaluated for antiradical activity and for inhibitory potential against DENV2 in Vero cells. This study tried to develop phytoterapics for dengue treatment using abundant natural resources.

\section{Materials and Methods}

2.1. Isolation and Purification of Galactomannans. Galactomannans were isolated from the endosperm of seeds of
D. gardneriana, A. pavonina, and C. ferrea. The methodology was reported by Vieira et al. [38]. Initially, approximately $73 \mathrm{~g}$ of seed species was boiled in $1 \mathrm{~L}$ of distilled water for 6 hours to promote enzyme inactivation and depigmentation. Then the seeds were immersed in water for 24 hours, and thereafter the swelling endosperm was manually separated from the embryo and the seed coat and subsequently lyophilized. To obtain the galactomannans, $10 \mathrm{~g}$ of isolated and freeze-dried endosperm was subjected to three consecutive exhaustive aqueous extractions. In each extraction $1 \mathrm{~L}$ of distilled water at $80^{\circ} \mathrm{C}$ (constant temperature) was used for a period of 6 hours until formation of a viscous solution. After this procedure, the aqueous extract was vacuum filtered on nylon sieve. The filtrate, a viscous liquid, was stored at $4^{\circ} \mathrm{C}$ and the solid retained on the sieve was subjected to two further extractions under the same conditions, until the entire endosperm is completely destroyed, leaving only insoluble fibers. At the end of the three exhaustive extractions with the same starting material, the liquids were stored together, with a total of $3 \mathrm{~L}$, which was vacuum filtered (through celite) and lyophilized.

2.2. Sulfation of Galactomannans and Purification of the Derivatives. According to Ono et al. [34] and Gamal-Eldeen et al. [39] the galactomannans ( $300 \mathrm{mg}$ ) were added to pyridine:formamide $(50: 10 \mathrm{v} / \mathrm{v})$ with stirring at $25^{\circ} \mathrm{C}(12$ hours) until finely dispersed suspensions were obtained. After the dispersion is completed, the mixture was cooled to $4^{\circ} \mathrm{C}$ and chlorosulfonic acid $(4 \mathrm{~mL})$ was slowly added to the mixtures with stirring over 24 hours at $4^{\circ} \mathrm{C}$. The resulting solutions were neutralized with saturated aqueous $\mathrm{NaHCO}_{3}$, dialyzed (molecular weight cutoff $8-12 \mathrm{kDa}$ ) for $120 \mathrm{~h}$ against distilled water and then centrifuged ( $8.800 \mathrm{rpm}, 25 \mathrm{~min})$. Three consecutive sulfating reactions were carried out and the sulfated derivate was collected after lyophilizing.

\subsection{Determination of Sulfate Content in Galactomannans.} The sulphate content of the sample (\%) was performed by absorption spectrophotometry in the UV-Visible and the degree of sulfation (DS) was determined by a turbidimetric method using the $\mathrm{BaCl}_{2}$-gelatin reagent [40]. The method has as principle, the complexion of barium sulfate to form an insoluble salt. Gelatin is used to keep the salt in suspension or increase the settling time of the formed salt. First $200 \mathrm{mg}$ of gelatin (Trade Oxide) is dissolved in $40 \mathrm{~mL}$ of hot water at $60-70^{\circ} \mathrm{C}$ then stored in the refrigerator for 12 hours. Thus, we obtained a mixture of barium and gelatin (transparent gelatinous fluid). After 12 hours, $200 \mathrm{mg}$ of barium chloride was added to the fluid and it was stored in the refrigerator for 3 hours. The polysaccharide was dissolved in $1 \mathrm{M}$ hydrochloric acid and subsequently hydrolyzed for five hours at $105-110^{\circ} \mathrm{C}$. A standard solution of anhydrous sodium sulfate $(1 \mathrm{mg} / \mathrm{mL})$ was used. After 20 minutes of standing at room temperature, the absorbance was measured at $360 \mathrm{~nm}$ and the assay was done in triplicate.

2.4. Infrared Spectroscopy Analysis. Infrared spectra (FTIR) of sulfated galactomannans were recorded from $\mathrm{KBr}$ pellets on BOMEM spectrometer, scanned between 4.000 and $500 \mathrm{~cm}^{-1}$. 
2.5. Evaluation of Antioxidant Capacity by Inhibition of Free Radical DPPH. To evaluate the antioxidant activity of sulfated galactomannans, the method reported by da Silva et al. [41], with some modifications, adopting the free radical DPPH (1,1-diphenyl-2-picrylhydrazyl), was used. The diluted samples $(1 \mathrm{~mL})$ were mixed with $2 \mathrm{~mL}$ of methanol solution containing DPPH radicals for $30 \mathrm{~min}$. Ascorbic acid (vitamin C) was used as positive control. The assay was done in triplicate and the tubes were shaken at the end of the additions by vortexing. The absorbance was measured at $517 \mathrm{~nm}$ for each concentration and the free radical scavenging effect in percent was calculated using the following formula: [ $\left(A_{0}-A-\right.$ $\left.\left.A_{b}\right) / A_{0}\right] \times 100$, where $A_{0}, A$, and $A_{b}$ indicate the absorbance of the methanol solution of DPPH, sample with solution of DPPH and sample without DPPH solution, respectively. $\mathrm{IC}_{50}$ values calculated denote the concentration of the sample required to decrease the absorbance at $517 \mathrm{~nm}$ by $50 \%$. The experiment was performed in triplicate.

2.6. Cells Culture. Vero cells were cultured in L-15 medium (Leibovitz-Cultilab, Brazil) supplemented with 10\% tryptose phosphate broth, 1\% penicillin/streptomycin (Gibco-BRL, USD) $(50 \mathrm{U} / \mathrm{mL}), 1 \%$ amphotericin B (Gibco-BRL, USD) $(250 \mu \mathrm{g} / \mathrm{mL})$, and $10 \%$ fetal bovine serum (FBS) (SigmaAldrich, USA) at $37^{\circ} \mathrm{C}$ in a $5 \% \mathrm{CO}_{2}$. For maintenance medium (MM), the FBS concentration was reduced to $2 \%$. Aedes albopictus $\mathrm{C}_{6 / 36}$ cells were maintained in 1-15 medium supplemented with $10 \%$ FBS and incubated at $28^{\circ} \mathrm{C}$ in a $5 \%$ $\mathrm{CO}_{2}$.

2.7. Dengue Virus Preparation. DENV-2 (strain New Guinea) was propagated in $\mathrm{C}_{6 / 36}$ cells. DENV-Infected $\mathrm{C}_{6 / 36}$ cells were incubated at $28^{\circ} \mathrm{C}$ for 7 days. After time, culture supernatants containing DENV-2 were collected. Viral suspension was prepared as described previously [34] and stored at $-80^{\circ} \mathrm{C}$. DENV-2 was titrated by cytopathogenicity and expressed as $50 \%$ tissue culture infectious dose $\left(\mathrm{TCID}_{50}\right) / \mathrm{mL}[42]$ in Vero cells.

2.8. Cytotoxicity Evaluation of Sulfated Galactomannans. The cytotoxicity of the sulfated polysaccharides against Vero cells was evaluated by the MTT (4,5-dimethylthiazol-2-yl)-2,5diphenyl tetrazolium bromide (Sigma-Aldrich, Germany) method, through the quantization of viable cells [30, 43, 44]. The cells were cultured in 96-well plates (TPP, Trasadingen, Switzerland), at a density of $2 \times 10^{5}$ cells/well. After a 24hour incubation period, at $37^{\circ} \mathrm{C}$ in an atmosphere of $\mathrm{CO}_{2}$, the culture medium was removed and the cells were washed three times with serum-free L- 15 , and polysaccharides diluted up to $200 \mu \mathrm{L} / \mathrm{mL}$ in $\mathrm{MM}$ were added to the cells. Untreated controls were performed by the addition of $200 \mu \mathrm{L}$ of MM. The cells were then incubated for 7 days. The medium was then removed and $50 \mu \mathrm{L}$ of MTT solution $(5 \mathrm{mg} / \mathrm{mL}$ ) was added. The plates were reincubated for $4 \mathrm{~h}$. After that, the MTT solution was removed, $100 \mu \mathrm{L}$ of DMSO was added to dissolve formazan crystals, and the plates were gently shaken, whereby crystals were completely dissolved. The solubilized product was quantified by spectrophotometry at $492 \mathrm{~nm}$ (reference at
$620 \mathrm{~nm})$. Results were expressed as \% inhibition considering absorbance control cells as $100 \%$ viable.

2.9. Inhibition of Virus Infection by Sulfated Galactomannans. The antiviral activity of the sulfated polysaccharides was also evaluated by the MTT method according to Silva et al. [30] with modification. Briefly, $100 \mu \mathrm{L}$ of viral suspension $\left(10^{2} \mathrm{TCID}_{50} / \mathrm{mL}\right)$ was mixed on ice with $100 \mu \mathrm{L}$ of sulfated polysaccharides at the indicated concentration and incubated at $37^{\circ} \mathrm{C}$ for $1 \mathrm{~h}$. The growth medium of confluent Vero cells, prepared at 96-well plates, was removed and cells were washed three times with serum-free L-15. Immediately, the virus-polysaccharides mixtures were inoculated onto the cells monolayers and incubated at $37^{\circ} \mathrm{C}$ for $1 \mathrm{~h}$. Cell and viral controls were performed by adding only $200 \mu \mathrm{L}$ of $\mathrm{MM}$ or $200 \mu \mathrm{L}$ of viral suspension, respectively. After the incubation period, the culture medium was removed and cells were again washed three times with serum-free L-15. The MM was added to the cells. Then the cells were incubated for 7 days. The percentages of viability of the dengue virus-infected cells were assayed by MTT colorimetric method as described above for the cytotoxicity assay and values were calculated as $[(A-B) \times$ $100 /(C-B)]$, where $A, B$, and $C$ indicate the absorbance of the polysaccharides, virus, and cell controls, respectively.

To detect the prevention of viral infection by sulfated polysaccharides, the assay was designed as follows: a negative control containing Vero cells, a positive control with DENV-2 infected cells, and test groups containing infected cells treated with sulfated polysaccharides. All groups were observed daily up to 7 days after infection by inverted microscope.

2.10. Solid-Phase Virus-Binding Assay. The existence of chemical affinity between DENV-2 for sulfated polysaccharides was evaluated through solid-phase virus-binding assay as described previously by Hidari et al. [8] with minor modifications. Briefly, sulfated polysaccharides in phosphate-buffered saline were immobilized on microtiter plates overnight. After blocking with PBS containing 5\% BSA, the plates were incubated for $2 \mathrm{~h}$ at $28^{\circ} \mathrm{C}$ with virus purification ( $5 \mu \mathrm{g} /$ well). After washing, the plates were incubated for $1 \mathrm{~h}$ at $28^{\circ} \mathrm{C}$ with human anti-dengue antiserum, followed by HRP-conjugated goat anti-human immunoglobulin. The complexes were detected by incubation with oPhenylenediamine. The absorbance was measured at $492 \mathrm{~nm}$.

2.11. Statistical Analysis. All the experiments on the antioxidant effect were calculated as means \pm standard deviation (SD). The one-way analysis of variance (ANOVA) test used to determine the statistical differences followed Tukey's multiple comparison tests. The criterion for statistical significance was $P<0.05$.

\section{Results and Discussion}

This work is the first report of the antioxidant and antiviral effects of sulfated galactomannans from A. pavonina (SGAP), D. gardneriana (SGDG), and C. ferrea (SGCF) against DENV2 in Vero cells. Ono et al. [34] demonstrated the inhibitory action of sulfated galactomannans from seeds of Mimosa 


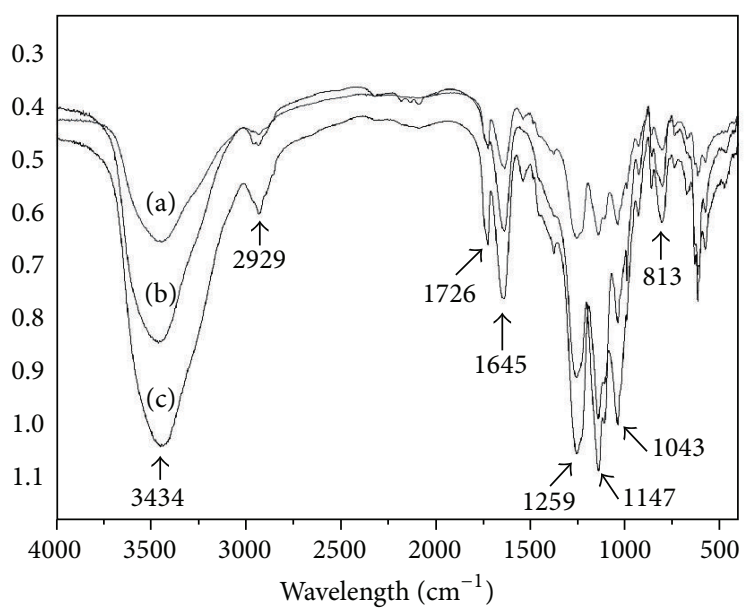

FIGURE 1: FT-IR of sulfated galactomannans from (a) Adenanthera pavonina, (b) Dimorphandra gardneriana, and (c) Caesalpinia ferrea. The absorption bands at $1259 \mathrm{~cm}^{-1}$ correspond to stretching vibrations of the $\mathrm{S}=\mathrm{O}$ bond.

scabrella and Leucaena leucocephala against DENV-1 in mosquito cells. Sulfated polysaccharides are potent inhibitors of DENV-2 in mammalian cell [5-8, 45, 46]. A differential susceptibility of DENV serotypes to sulfated polysaccharides was showed in Vero and BHK-21 cells, in the order DENV-2 > DENV-3 > DENV-4 > DENV-1 [10].

The presence of sulfate groups in galactomannans derivatives was confirmed by their IR spectra which contained a high-intensity absorption band at $1.259 \pm 3 \mathrm{~cm}^{-1}$ which was assigned to stretching vibrations of the $\mathrm{S}=\mathrm{O}$ bond and a moderate intensity band at $813 \mathrm{~cm}^{-1}$ indicating a C-O-S vibration (Figure 1). These results indicated that galactomannans from D. gardneriana, A. pavonina, and C. ferrea seeds were successfully sulfated [47].

To measure Vero cell viability treated with SGAP, SGDG, and SGCF, MTT spectrophometric assay was used. No cytotoxicity was observed for any of the sulfated galactomannans in concentrations of 25,50 , and $100 \mu \mathrm{g} / \mathrm{mL}$ up to 7 days. In all the antiviral experiments $25 \mu \mathrm{g} / \mathrm{mL}$ of each compound was used.

The use of entrance inhibitor in enveloped viruses is a very attractive strategy for therapeutic intervention, as the site of action of the inhibitor is likely to be extracellular and therefore relatively accessible, and this could also limit cell toxicity [48]. Studies demonstrated that fucoidan and chondroitin sulphate $\mathrm{E}$ has antiviral activity against DENV by direct binding of these compounds to the virus $[8,9]$. This study showed that DENV-2 bound to SGAP, SGDG, and SGCF (Figure 2), and this binding may be responsible for the inhibitory activity of sulfated galactomannans (Figure 3).

The inhibitory potential of SGAP, SGDG, and SGCF against DENV-2 was measured using MTT assay. It was noted that absorbance at $492 \mathrm{~nm}$ is directly proportional to the number of living cells in the culture and converted into percent viability, which represent the potency of inhibition by compounds. The measurement of cell viability with values of $70 \%$ or above is considered to be prominent with relevant

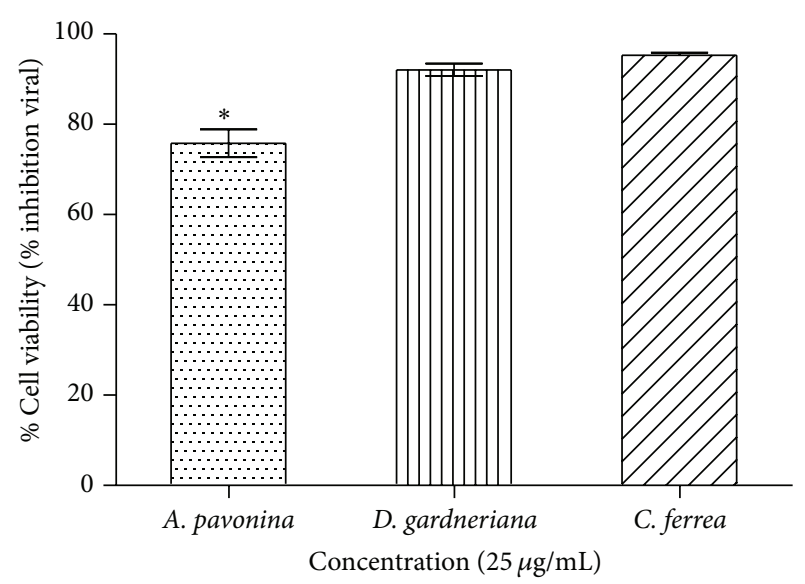

FIGURE 2: Antiviral activity of sulfated galactomannans: cell viability of the DENV-2-infected Vero cells treated with galactomannans. Statistical significance was determined by Tukey's multiple comparison tests $\left({ }^{*} P<0.05\right)$.

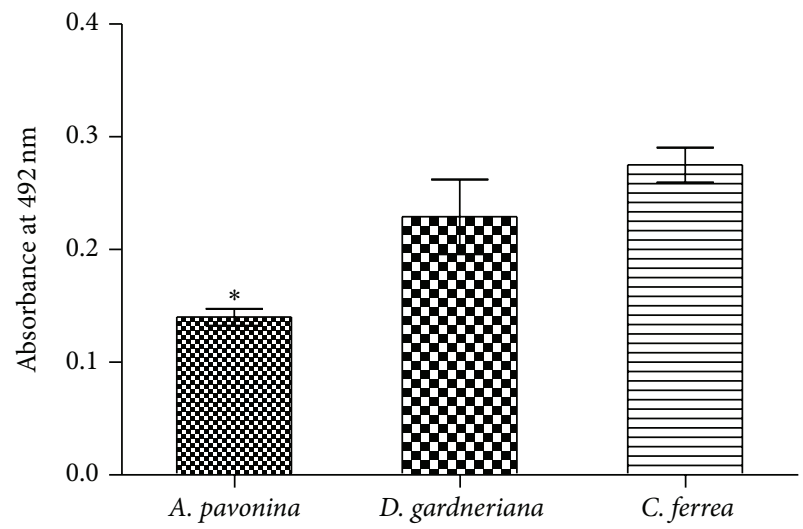

FIGURE 3: Binding activity of DENV-2 in relation to sulfated galactomannans from A. pavonina, D. gardneriana, and C. ferrea inimmobilized plastic plates. The bound of dengue virus to compounds was detected by measuring the absorbance at $492 \mathrm{~nm}$. Statistical significance was determined by Tukey's multiple comparison tests $(P<0.05)$.

significance [4]. The results demonstrated that all sulfated polysaccharides had inhibitory activity at $25 \mu \mathrm{g} / \mathrm{mL}$. SGCF exhibited $96 \%$ of inhibition against DENV-2, followed by SGDG (94\%) e SGAP (77\%) (Figure 3). The morphology of cells treated with SGAP, SGDG, and SGCF was shown to be similar to negative control (Vero cells) up to 7 days after infection. As a positive control Vero cells infected with DENV-2 were used; in those, it was observed that about $80 \%$ of the monolayer was damaged up to 7 days after infection. Therefore, the results indicated protective activity of sulfated galactomannans (Figure 4).

According to the results of the experiment, it was possible to verify a positive correlation between antiviral activity against DENV-2 and DS $\left(R^{2}=0.812\right)$, and these data corroborate Qiu et al. [49] who mention DS as a relevant parameter for the antiviral activity of a polymer on dengue 


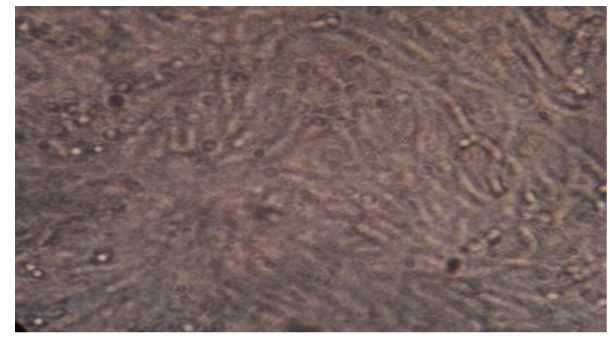

(a)

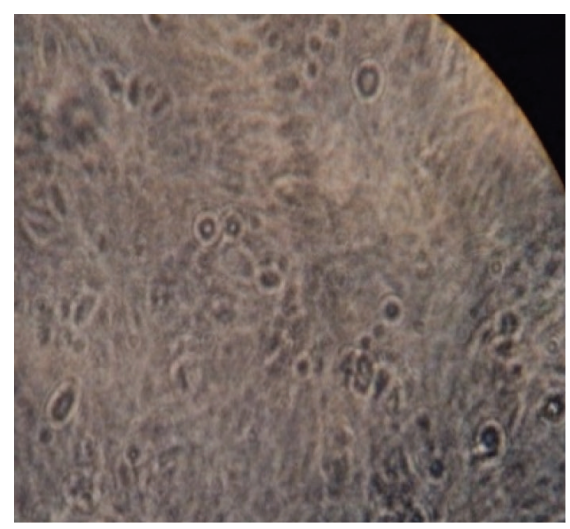

(c)

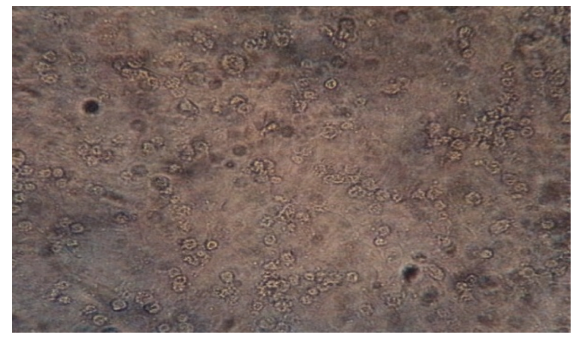

(b)

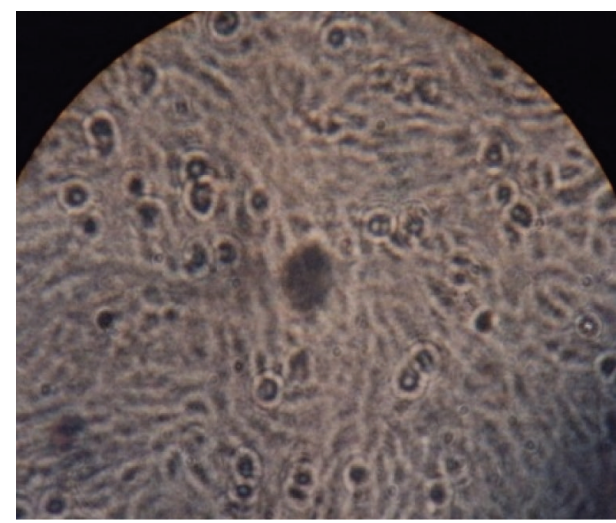

(d)

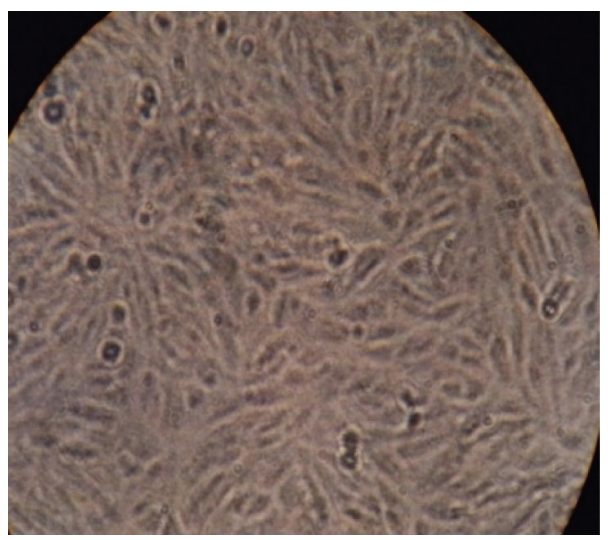

(e)

Figure 4: Morphological profile of Vero cell treated or not with sulfated galactomannans $(25 \mu \mathrm{g} / \mathrm{mL})$ up to 7 days after infection (400x). (a) Normal Vero cell (negative control), (b) infected Vero cell with DENV-2, (c) cell treated with A. pavonina (SGAP), (d) cell treated with D. gardneriana (SGDG), and (e) cell treated with C. ferrea (SGCF). The compounds showed protective activity against DENV-2.

virus infection. Research has shown that sulfated groups are fundamental for viral action against dengue virus [50]. The sulfated polysaccharides acted as HS-mimetic substances, interfering with the interaction of E glycoprotein with the cellular HS receptor and blocking the interaction.

Ichiyama et al. [51] demonstrated that curdlan sulfate, a sulfated $1 \rightarrow 3-\beta-\mathrm{D}$ glucan, has already been tested in humans as inhibition of HIV virus entry without serious side effects and also showed action against dengue virus in vitro, which characterizes it as a possible candidate for clinical application. This result opens perspectives to test the sulfated galactomannans SGAP, SGDG, and SGCF in clinical trials, since they displayed inhibitory action against DENV-2 virus without any toxicity in the tested concentrations.

Inhibition of DPPH radical by sulfated galactomannans and vitamin $C$ is shown in Table 1. Wang et al. [47] showed that sulfated galactomannans from guar gum with several DS, in the DPPH test, were found to have strong scavenging activity. In the present work, the SGCF shows also a strong antioxidant activity with $\mathrm{IC}_{50}=0.94 \mu \mathrm{g} / \mathrm{mL}$, much better compared to SGDG and SGAP with $\mathrm{IC}_{50}=7.56$ and $\mathrm{IC}_{50}=$ $7.51 \mu \mathrm{g} / \mathrm{mL}$, respectively. The sulfated galactomannans from A. pavonina (SGAP), D. gardneriana (SGDG), and C. ferrea (SGCF) had a sulfate content of $33.9 \%, 35.7 \%$, and $39.0 \%$, 
TABLE 1: Sulfate yield (\%) of galactomanans and inhibition concentration $\left(\mathrm{IC}_{50}\right)$ of DPPH.

\begin{tabular}{lccc}
\hline Galactomannans & Sulfate yield $(\%)$ & DS & $\mathrm{IC}_{50}(\mu \mathrm{g} / \mathrm{mL}) \pm \mathrm{SD}$ \\
\hline A. pavonina & $33.9 \pm 0.6^{\mathrm{a}}$ & $0.72 \pm 0.04^{\mathrm{a}}$ & $7.51 \pm 0.03^{\mathrm{a}}$ \\
D. gardneriana & $35.7 \pm 0.1^{\mathrm{b}}$ & $0.75 \pm 0.02^{\mathrm{a}}$ & $7.56 \pm 0.04^{\mathrm{a}}$ \\
C. ferrea & $39.0 \pm 0.3^{\mathrm{c}}$ & $0.82 \pm 0.01^{\mathrm{b}}$ & $0.94 \pm 0.01^{\mathrm{b}}$ \\
Vitamin C & - & - & $0.48 \pm 0.01^{\mathrm{b}}$ \\
\hline
\end{tabular}

Different letters mean significant differences within the lines. IC $_{50}$ means \pm standard deviation (SD). DS: sulfating degree.

respectively. The degree of sulfating (DS) of SGCF (0.82) was higher than that of SGDG (0.75) and SGAP (0.72), as shown in Table 1 . The antioxidant activity was related to the DS and results show that sulfate group plays an important role in antiradical activity of sulfated galactomannans. The mechanism of antioxidant action probably is due to hydrogen-donating ability of sulfate groups. According to Teissier et al. [48], sulfated galactomannans from guar gum with several DS, in the DPPH test, were found to have strong antioxidant activities with scavenging property. Viral infections are accompanied with profound changes in cell/tissue metabolism, which lead to generation of reactive oxygen species and may enhance the pathogenesis of the infection. Therefore the use of antioxidants can be of great value in preventing the inception or the progression of the virus disease [52].

\section{Conclusion}

In conclusion, antioxidant and antiviral effects were observed for sulfated galactomannans from seeds of A. pavonina, D. gardneriana, and C. ferrea and these are directly related to sulfating degree. The investigation of mechanism of action of sulfated galactomannans from plants of Caatinga biome suggests an effect in the early step of viral infection and may act as an entry inhibitor of DENV-2. Further tests are needed to evaluate the antiviral activity of these compounds in vivo.

\section{Conflict of Interests}

The authors have declared that there is no conflict of interests.

\section{Acknowledgments}

The authors thank the Brazilian governmental agencies CAPES and FUNCAP (Ceará State Research Funding) for their financial support.

\section{References}

[1] D. J. Gubler, "Epidemic dengue/dengue hemorrhagic fever as a public health, social and economic problem in the 21st century," Trends in Microbiology, vol. 10, no. 2, pp. 100-103, 2002.

[2] World Health Organization (WHO), Dengue: The Fastest Growing Mosquito-Borne Disease in the Word, World Health Organization (WHO), Geneva, Switzerland, 2010, http://www.who.int/ entity/neglected_diseases/integrated_media/integrated_media 2010_Dengue_vs_malaria/en/.

[3] WHO (World Health Organization), "Dengue," in Guidelines for Treatment, Prevention and Control, WHO, Geneva, Switzerland,
2009, http://www.who.int/tdr/publications/documents/denguediagnosis.pdf/.

[4] M. Muhamad, L. Y. Kee, N. A. Rahman, and R. Yusof, "Antiviral actions of flavanoid-derived compounds on dengue virus type2," International Journal of Biological Sciences, vol. 6, no. 3, pp. 294-302, 2010.

[5] C. A. Pujol, J. M. Estevez, M. J. Carlucci, M. Ciancia, A. S. Cerezo, and E. B. Damonte, "Novel DL-galactan hybrids from the red seaweed Gymnogongrus torulosus are potent inhibitors of herpes simplex virus and dengue virus," Antiviral Chemistry and Chemotherapy, vol. 13, no. 2, pp. 83-89, 2002.

[6] L. B. Talarico, C. A. Pujol, R. G. M. Zibetti et al., "The antiviral activity of sulfated polysaccharides against dengue virus is dependent on virus serotype and host cell," Antiviral Research, vol. 66, no. 2-3, pp. 103-110, 2005.

[7] P. C. de S.F-Tischer, L. B. Talarico, M. D. Noseda, S. M. P. B. Guimarães, E. P. Damonte, and M. E. R. Duarte, "Chemical structure and antiviral activity of carrageenans from Meristiella gelidium against herpes simplex and dengue virus," Carbohydrate Polymers, vol. 63, no. 4, pp. 459-465, 2006.

[8] K. I. P. J. Hidari, N. Takahashi, M. Arihara, M. Nagaoka, K. Morita, and T. Suzuki, "Structure and anti-dengue virus activity of sulfated polysaccharide from a marine alga," Biochemical and Biophysical Research Communications, vol. 376, no. 1, pp. 91-95, 2008.

[9] D. Kato, S. Era, I. Watanabe et al., "Antiviral activity of chondroitin sulphate E targeting dengue virus envelope protein," Antiviral Research, vol. 88, no. 2, pp. 236-243, 2010.

[10] E. G. Acosta, L. B. Talarico, and E. B. Damonte, "Cell entry of dengue virus," Future Virology, vol. 3, no. 5, pp. 471-479, 2008.

[11] Y. Chen, T. Maguire, R. E. Hileman et al., "Dengue virus infectivity depends on envelope protein binding to target cell heparan sulfate," Nature Medicine, vol. 3, no. 8, pp. 866-871, 1997.

[12] L. B. Talarico and E. B. Damonte, "Interference in dengue virus adsorption and uncoating by carrageenans," Virology, vol. 363, no. 2, pp. 473-485, 2007.

[13] T. Akaike, M. Suga, and H. Maeda, "Free radicals in viral pathogenesis: molecular mechanisms involving superoxide and NO," Proceedings of the Society for Experimental Biology and Medicine, vol. 217, no. 1, pp. 64-73, 1998.

[14] T.-H. Chen, Y.-P. Lo, C.-F. Yang, and W.-J. Chen, "Additive protection by antioxidant and apoptosis-inhibiting effects on mosquito cells with dengue 2 virus infection," PLoS Neglected Tropical Diseases, vol. 6, no. 4, Article ID e1613, 2012.

[15] A. Hussain, A. Rizvi, S. Wahab, I. Zareen, S. Ansari, and S. Hussain, "Antibacterial screening of the bark of Adenanthera pavonina," International Journal of Biomedical Research, vol. 2, no. 2, pp. 110-122, 2011.

[16] O. A. Adeyemi, A. D. Adedapo, A. A. Adepapo, and J. O. Moody, "Evaluation of the antimicrobial activity of crude extracts 
and chromatographic fractions of Adenanthera pavonina Linn (Leguminosae) seeds," African Journal of Biotechnology, vol. 14, no. 12, pp. 1067-1073, 2015.

[17] I. K. Silva and P. Soysa, "Evaluation of phytochemical composition and antioxidant capacity of a decoction containing Adenanthera pavonina L. and Thespesia populnea L.," Pharmacognosy Magazine, vol. 7, no. 27, pp. 193-199, 2011.

[18] S. Dash, C. Das, and D. C. Sahoo, "Phytochemical and anthelmintic screening of crude bark extract of Adenanthera pavonina Linn.," International Journal of Comprehensive Pharmacy, vol. 2, pp. 1-4, 2010.

[19] S. Das, S. Dash, A. C. Sahoo, R. K. Giri, D. C. Sahoo, and P. Guru, "Anti-hyperlipidemic activity of Adenanthera pavonina Linn. ethanolic bark extract fractions," Nature Pharmacy Technology, vol. 1, pp. 1-4, 2011.

[20] A. D. A. Adedapo, Y. O. Osude, A. A. Adedapo et al., "Blood pressure lowering effect of Adenanthera pavonina seed extract on normotensive rats," Records of Natural Products, vol. 3, pp. 82-89, 2009.

[21] A. Ara, M. Arifuzzaman, C. K. Ghosh et al., "Anti-inflammatory activity of Adenanthera pavonina L., Fabaceae, in experimental animals," Brazilian Journal of Pharmacognosy, vol. 20, no. 6, pp. 929-932, 2010.

[22] C. F. B. Vasconcelos, H. M. L. Maranhão, T. M. Batista et al., "Hypoglycaemic activity and molecular mechanisms of Caesalpinia ferrea Martius bark extract on streptozotocin-induced diabetes in Wistar rats," Journal of Ethnopharmacology, vol. 137, no. 3, pp. 1533-1541, 2011.

[23] S. K. Hassan, N. M. El-Sammad, A. M. Mousa et al., "Hypoglycemic and antioxidant activities of Caesalpinia ferrea Martius leaf extract in streptozotocin-induced diabetic rats," Asian Pacific Journal of Tropical Biomedicine, vol. 5, no. 6, pp. 462-471, 2015.

[24] F. C. Sampaio, M. D. S. V. Pereira, C. S. Dias, V. C. O. Costa, N. C. O. Conde, and M. A. R. Buzalaf, "In vitro antimicrobial activity of Caesalpinia ferrea martius fruits against oral pathogens," Journal of Ethnopharmacology, vol. 124, no. 2, pp. 289-294, 2009.

[25] E. S. Nakamura, F. Kurosaki, M. Arisawa et al., "Cancer chemopreventive effects of constituents of Caesalpinia ferrea and related compounds," Cancer Letters, vol. 177, no. 2, pp. 119124, 2002.

[26] H. Nozaki, K.-I. Hayashi, M. Kido et al., "Pauferrol A, a novel chalcone trimer with a cyclobutane ring from Caesalpinia ferrea mart exhibiting DNA topoisomerase II inhibition and apoptosis-inducing activity," Tetrahedron Letters, vol. 48, no. 47, pp. 8290-8292, 2007.

[27] L. D. P. Pereira, R. O. D. Silva, P. H. D. S. F. Bringel, K. E. S. D. Silva, A. M. S. Assreuy, and M. G. Pereira, "Polysaccharide fractions of Caesalpinia ferrea pods: potential anti-inflammatory usage," Journal of Ethnopharmacology, vol. 139, no. 2, pp. 642648, 2012.

[28] S. M. A. Lima, L. C. C. Araújo, M. M. Sitônio et al., "Anti-inflammatory and analgesic potential of Caesalpinia ferrea," Brazilian Journal of Pharmacognosy, vol. 22, no. 1, pp. 169-175, 2011.

[29] M. I. Azevedo, A. F. Pereira, R. B. Nogueira et al., "The antioxidant effects of the flavonoids rutin and quercetin inhibit oxaliplatin-induced chronic painful peripheral neuropathy," Molecular Pain, vol. 9, article 53, 2013.

[30] A. R. A. Silva, S. M. Morais, M. M. M. Marques et al., "Antiviral activities of extracts and phenolic components of two Spondias species against dengue virus," Journal of Venomous Animals and
Toxins Including Tropical Diseases, vol. 17, no. 4, pp. 406-413, 2011.

[31] H. Chen, Q. Miao, M. Geng et al., "Anti-tumor effect of rutin on human neuroblastoma cell lines through inducing G2/M cell cycle arrest and promoting apoptosis," The Scientific World Journal, vol. 2013, Article ID 269165, 8 pages, 2013.

[32] H. Yoo, S.-K. Ku, Y.-D. Baek, and J.-S. Bae, "Anti-inflammatory effects of rutin on HMGB1-induced inflammatory responses in vitro and in vivo," Inflammation Research, vol. 63, no. 3, pp. 197206, 2014.

[33] N. S. Vila-Nova, S. M. Morais, M. J. C. Falcão et al., "Leishmanicidal and cholinesterase inhibiting activities of phenolic compounds of Dimorphandra gardneriana and Platymiscium floribundum, native plants from Caatinga biome," Pesquisa Veterinaria Brasileira, vol. 32, no. 11, pp. 1164-1168, 2012.

[34] L. Ono, W. Wollinger, I. M. Rocco, T. L. M. Coimbra, P. A. J. Gorin, and M.-R. Sierakowski, "In vitro and in vivo antiviral properties of sulfated galactomannans against yellow fever virus (BeH111 strain) and dengue 1 virus (Hawaii strain)," Antiviral Research, vol. 60, no. 3, pp. 201-208, 2003.

[35] F. Chrestani, M. R. Sierakowski, D. E. de Andrade Uchoa et al., "In vitro antiherpetic and antirotaviral activities of a sulfate prepared from Mimosa scabrella galactomannan," International Journal of Biological Macromolecules, vol. 45, no. 5, pp. 453-457, 2009.

[36] E. Gemin, C. E. O. Ferreira, M. R. Sierakowski, T. R. Jorge, M. E. G. Joineau, and L. Ono, "In vitro anti-HSV-1 activity of a chemically sulfated galactomannan from Leucaena leucocephala seeds," Revista Ciencias Farmacêutica Basica e Aplicada, vol. 31, no. 2, pp. 165-170, 2010.

[37] N. Lopes, L. C. Faccin-Galhardi, S. F. Espada et al., "Sulfated polysaccharide of Caesalpinia ferrea inhibits herpes simplex virus and poliovirus," International Journal of Biological Macromolecules, vol. 60, pp. 93-99, 2013.

[38] Í. G. P. Vieira, F. N. P. Mendes, M. I. Gallão, and E. S. de Brito, "NMR study of galactomannans from the seeds of mesquite tree (Prosopis juliflora (Sw) DC)," Food Chemistry, vol. 101, no. 1, pp. 70-73, 2006.

[39] A. M. Gamal-Eldeen, H. Amer, and W. A. Helmy, "Cancer chemopreventive and anti-inflammatory activities of chemically modified guar gum," Chemico-Biological Interactions, vol. 161, no. 3, pp. 229-240, 2006.

[40] K. S. Dodgson, "Determination of inorganic sulphate in studies on the enzymic and non-enzymic hydrolysis of carbohydrate and other sulphate esters," The Biochemical Journal, vol. 78, pp. 312-319, 1961.

[41] A. R. A. da Silva, S. M. de Morais, M. M. M. Marques et al., "Chemical composition, antioxidant and antibacterial activities of two Spondias species from Northeastern Brazil," Pharmaceutical Biology, vol. 50, no. 6, pp. 740-746, 2012.

[42] L. J. Reed and H. A. Muench, "A simple method of estimating fifty per cent endpoints," American Journal of Epidemiology, vol. 27, no. 3, pp. 493-497, 1938.

[43] T. Mosmann, "Rapid colorimetric assay for cellular growth and survival: application to proliferation and cytotoxicity assays," Journal of Immunological Methods, vol. 65, no. 1-2, pp. 55-63, 1983.

[44] A. M. Sieuwerts, J. G. M. Klijn, H. A. Peters, and J. A. Foekens, "The MTT tetrazolium salt assay scrutinized: how to use this assay reliably to measure metabolic activity of cell cultures in vitro for the assessment of growth characteristics, $\mathrm{IC}_{50}$-values 
and cell survival," European Journal of Clinical Chemistry and Clinical Biochemistry, vol. 33, no. 11, pp. 813-823, 1995.

[45] Y.-L. Lin, H.-Y. Lei, Y.-S. Lin, T.-M. Yeh, S.-H. Chen, and H.-S. Liu, "Heparin inhibits dengue-2 virus infection of five human liver cell lines," Antiviral Research, vol. 56, no. 1, pp. 93-96, 2002.

[46] L. B. Talarico, M. E. R. Duarte, R. G. M. Zibetti, M. D. Noseda, and E. B. Damonte, "An algal-derived DL-galactan hybrid is an efficient preventing agent for in vitro dengue virus infection," Planta Medica, vol. 73, no. 14, pp. 1464-1468, 2007.

[47] X. Wang, J. Wang, J. Zhang, B. Zhao, J. Yao, and Y. Wang, "Structure-antioxidant relationships of sulfated galactomannan from guar gum," International Journal of Biological Macromolecules, vol. 46, no. 1, pp. 59-66, 2010.

[48] E. Teissier, F. Penin, and E.-I. Pécheur, "Targeting cell entry of enveloped viruses as an antiviral strategy," Molecules, vol. 16, no. 1, pp. 221-250, 2011.

[49] H. Qiu, W. Tang, X. Tong, K. Ding, and J. Zuo, "Structure elucidation and sulfated derivatives preparation of two $\alpha$-D-glucans from Gastrodia elata $\mathrm{Bl}$. and their anti-dengue virus bioactivities," Carbohydrate Research, vol. 342, no. 15, pp. 2230-2236, 2007.

[50] R. R. Teixeira, W. L. Pereira, A. F. C. da Silveira Oliveira et al., "Natural products as source of potential dengue antivirals," Molecules, vol. 19, no. 6, pp. 8151-8176, 2014.

[51] K. Ichiyama, S. B. Gopala Reddy, L. F. Zhang et al., "Sulfated polysaccharide, curdlan sulfate, efficiently prevents entry/fusion and restricts antibody-dependent enhancement of dengue virus infection in vitro: a possible candidate for clinical application," PLoS Neglected Tropical Diseases, vol. 7, no. 4, Article ID e2188, 2013.

[52] H. Edziri, M. Mastouri, M. Aouni, and L. Verschaeve, "Polyphenols content, antioxidant and antiviral activities of leaf extracts of Marrubium deserti growing in Tunisia," South African Journal of Botany, vol. 80, pp. 104-109, 2012. 


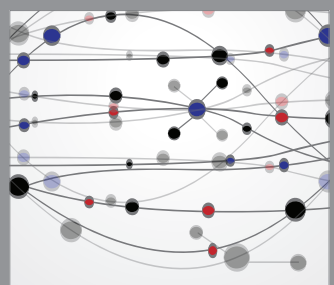

The Scientific World Journal
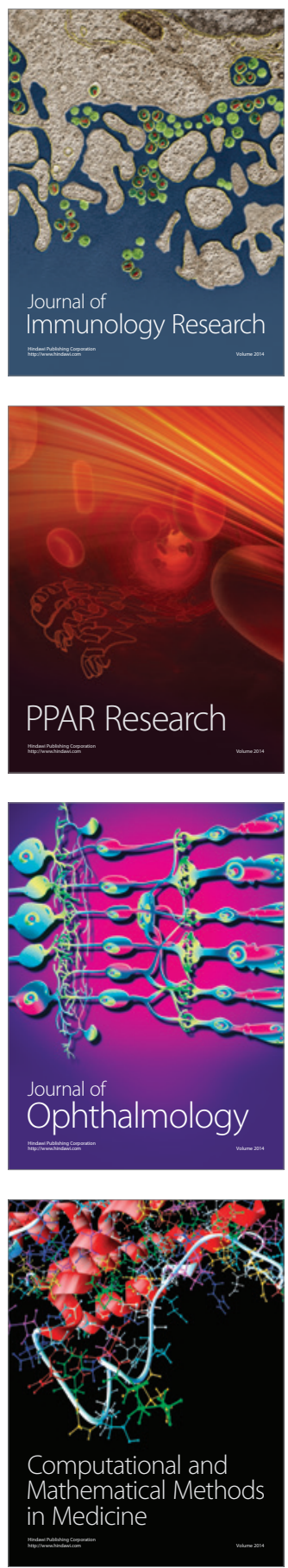

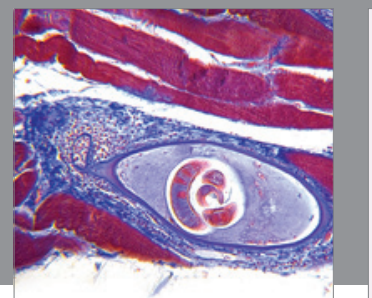

Gastroenterology

Research and Practice
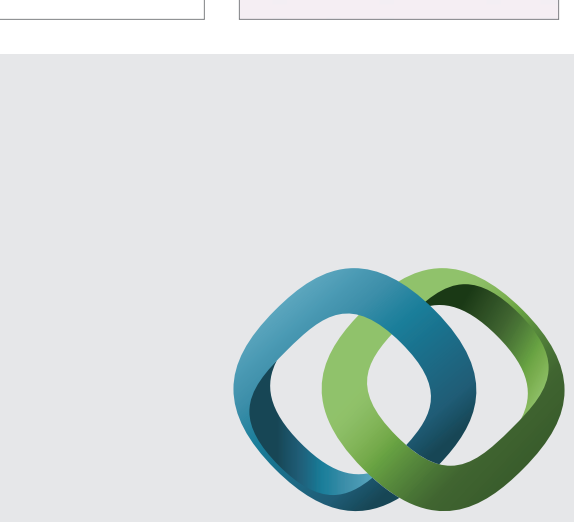

\section{Hindawi}

Submit your manuscripts at

http://www.hindawi.com
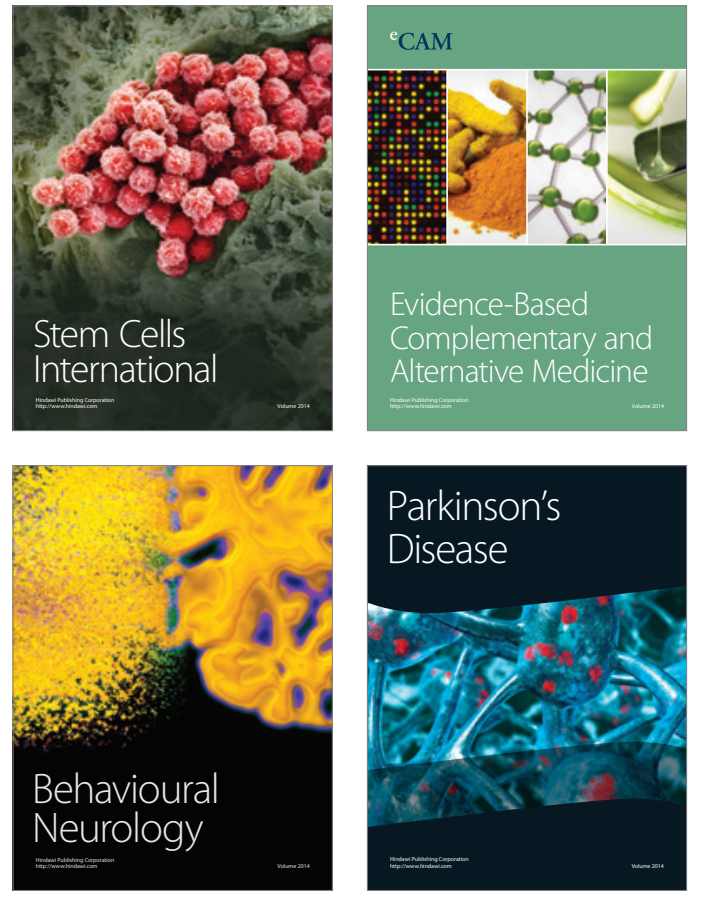
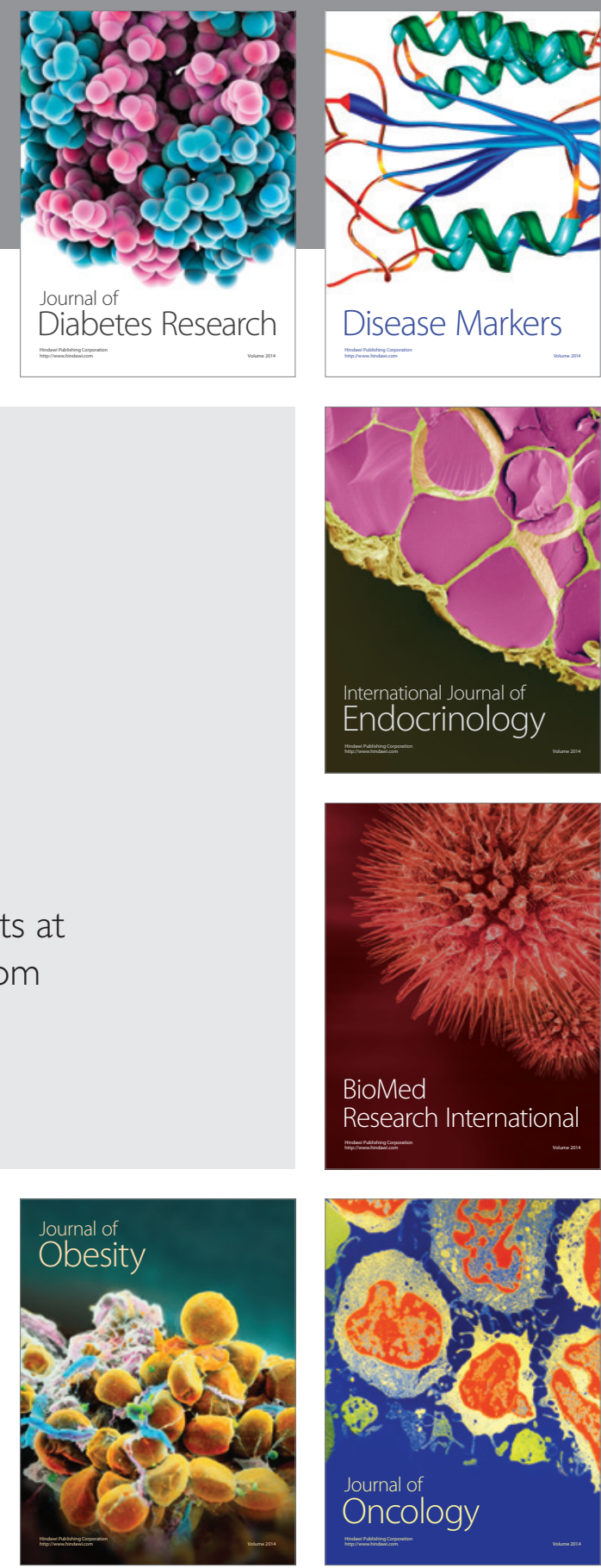

Disease Markers
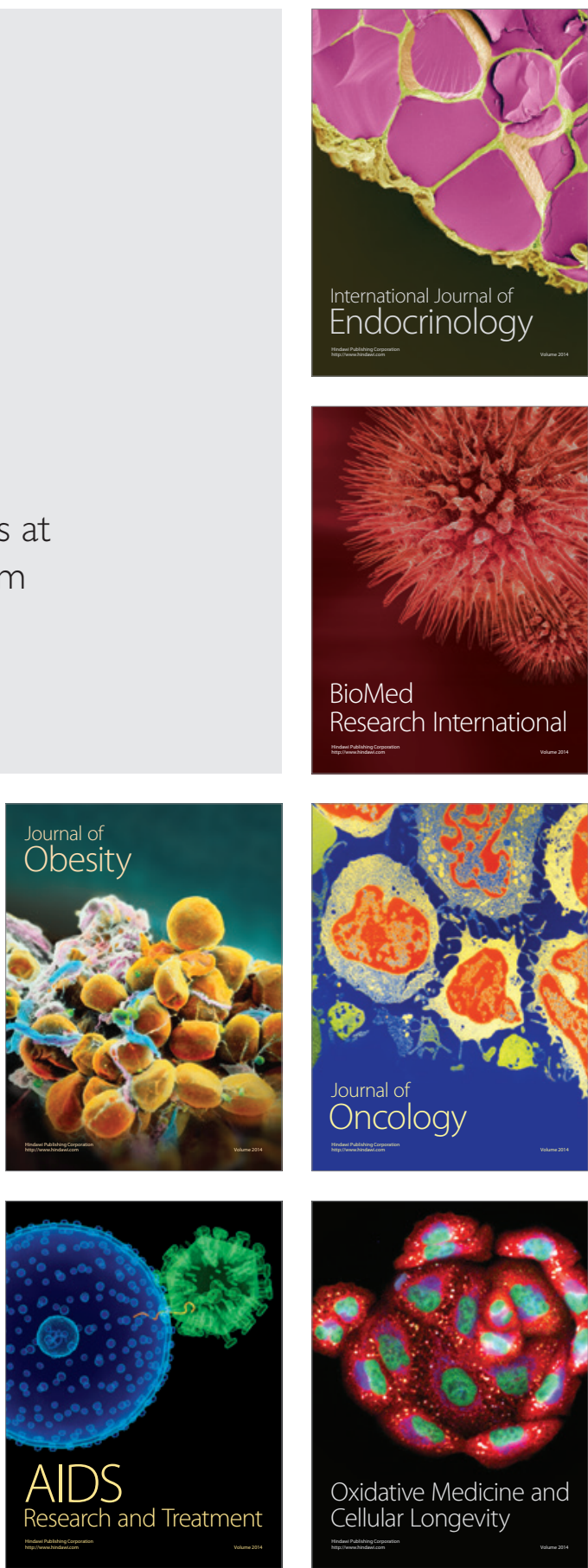